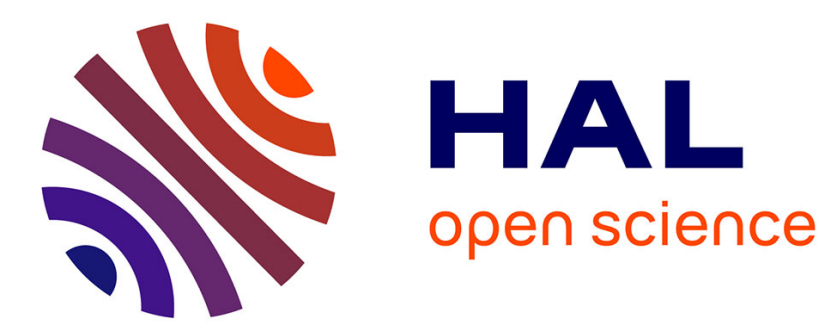

\title{
Kant and real numbers
}

Mark van Atten

\section{To cite this version:}

Mark van Atten. Kant and real numbers. Peter Dybjer, Sten Lindström, Erik Palmgren, Göran Sundholm. Epistemology versus Ontology: Essays on the Philosophy and Foundations of Mathematics in Honour of Per Martin-Löf, 27, Springer, pp.203-213, 2012, Logic, Epistemology, and the Unity of Science, 978-94-007-4434-9. 10.1007/978-94-007-4435-6_10 . halshs-00775352

\section{HAL Id: halshs-00775352 https://shs.hal.science/halshs-00775352}

Submitted on 21 Feb 2017

HAL is a multi-disciplinary open access archive for the deposit and dissemination of scientific research documents, whether they are published or not. The documents may come from teaching and research institutions in France or abroad, or from public or private research centers.
L'archive ouverte pluridisciplinaire HAL, est destinée au dépôt et à la diffusion de documents scientifiques de niveau recherche, publiés ou non, émanant des établissements d'enseignement et de recherche français ou étrangers, des laboratoires publics ou privés.

\section{(c)(1)}

Distributed under a Creative Commons Attribution| 4.0 International License 


\title{
Kant and real numbers
}

\author{
Mark van Atten \\ SND (CNRS / Paris IV), , rue Victor Cousin, 75005 Paris, France. \\ vanattenmark@gmail.com \\ dedicated to Per Martin-Löf
}

\begin{abstract}
Kant held that under the concept of $\sqrt{ } 2$ falls a geometrical magnitude, but not a number. In particular, he explicitly distinguished this root from potentially infinite converging sequences of rationals. Like Kant, Brouwer based his foundations of mathematics on the a priori intuition of time, but unlike Kant, Brouwer did identify this root with a potentially infinite sequence. In this paper I discuss the systematical reasons why in Kant's philosophy this identification is impossible.
\end{abstract}

I Introduction

Consider the following three concepts:

I. The square root of 2

2. The diagonal of a square with sides of length 1

3. The infinite sequence of rational numbers

$$
1,1.4,1.41, \ldots
$$

given by a rule that ensures that the square of the successive rationals converges to 2 . 
Nowadays we say that under each of these concepts falls an object. The length of the diagonal of the square is given by $\sqrt{ } 2$ but this root exists independently from geometry. $\sqrt{ } 2$ is a real number, and this real number can, if one wishes to do so, be identified with the infinite sequence determined by the third concept (or, alternatively, an equivalence class of such sequences).

But Kant stopped short, like a horse in front of a fence, of introducing real numbers by identifying them with infinite sequences. Indeed, he viewed the relations between the three concepts above differently. The main source that documents Kant's view on real numbers is his reply of Autumn 1790 to a letter from August Rehberg. 'This view was, as such, perfectly traditional in Kant's days ${ }^{2}$ but it is interesting to see that they readily fit his newly proposed foundations of mathematics: ${ }^{3}$

I. Rehberg's letter: AA XI:205-206; Kant's reply: AA XI:207-210. Rehberg did not reply in turn, but much later published excerpts from Kant's letter to him, together with his dissatisfied comments on it, in the first volume of his Saemtliche Schriften of I 828 (Rehberg I828, pp. 52-60). With the publication of Kant's Nachlass, also two drafts for his reply to Rehberg became known (AA XIV:53-55,55-59). For an amusing description of Rehberg, see Jachmann's letter to Kant of October I4, I790, AA XI:215-227, in particular p. 225. It is Jachmann's letter that tells us that Rehberg's letter came to Kant via Nicolovius. For detailed information on Rehberg's life and work, see Beiser 2008.

2. However, Stevin had already argued in 1585 that $\sqrt{ } 8$ is a number because it is part of 8 , which is a number: 'La partie est de la mesme matiere qu'est son entier; Racine de 8 est partie de son quarré 8 : Doncques $\sqrt{ } 8$ est de la mesme matiere qu'est $8:$ Mais la matiere de 8 est nombre; Doncques la matiere de $\sqrt{ } 8$ est nombre : Et par consequent $\sqrt{ } 8$, est nombre.' Of course, Stevin did not go on to provide an arithmetization of real numbers (Stevin I585, p. 30).

3. Kant did not publish this view in his lifetime, and it seems it first appeared in print in Rehberg's later comments on their exchange (Rehberg I828, pp. 52-60). However, three remarks to the same effect were published within a framework close to Kant's in Solomon Maimon's book on Kant's philosophy, Versuch über die Transscendentalphilosophie of Autumn I789, the year before Kant's exchange with Rehberg (1790; the title page states I790, but see its editor's remark in footnote I on p. II of the edition used here). The remarks in question appear on p. 374, 229/374, and 374, respectively. There seems to be no evidence as to whether Kant had seen Maimon's remarks before writing to Rehberg (or later). (Warda's list (Warda 1922) and the more comprehensive database 'Kants Lektüre' (URL = http://web.uni-marburg.de/kant/ webseitn/ka_lektu.htm) suggest that Kant did not own Maimon's book. But that does not show that he did not see it at some point.) Note that Rehberg, in his later comments (Rehberg 
I. The concept of the magnitude $\sqrt{ } 2$ is not empty, because it can be instantiated geometrically:

That a middle proportional magnitude can now be found between one that equals 1 and another that equals 2, and is therefore not an empty concept (without an object), geometry shows with the diagonal of the square. (AA XI:208) ${ }^{4}$

2. But $\sqrt{ } 2$ cannot be instantiated numerically, because genuine numbers are composed out of units and hence rational:

But the pure schema of magnitude (quantitatis), as a concept of the understanding, is number, a representation which comprises the successive addition of homogeneous units. (Ar42/Bi82, also referred to by Rehberg)s

So the only question is why for this quantum $[\sqrt{ } 2]$ no number can be found that represents the quantity (the ratio to unity) clearly and completely in a concept. ... That, however, the understanding, which arbitrarily makes for itself the concept of $\sqrt{ } 2$, cannot also bring forth the complete number concept, namely its rational ratio to unity, ... (AA XI:208)

I828), does not mention Maimon's book either. We will come back to the exchange between Rehberg and Kant from a systematical point of view in Sect. 3. Note added in 20I7: That database can now be found at http://www.online.uni-marburg.de/kant_old/webseitn/ka_ lektu.htm.

4. ' $\mathrm{Daß}$ nun die mittlere Proportionalgröße zwischen einer die $=1$ und einer anderen welche $=2$ gefunden werden könne, mithin jene kein leerer Begrif (ohne Object) sey, zeigt die Geometrie an der Diagonale des Qvadrats.'

5. 'Das reine Schema der Größe aber (quantitatis), als eines Begriffs des Verstandes, ist die Zahl, welche eine Vorstellung ist, die die sukzessive Addition von Einem zu Einem (gleichartigen) zusammenbefaßt.'

6. 'Es ist also nur die Frage warum für dieses Qvantum $[\sqrt{ } 2]$ keine Zahl gefunden werden könne 
3. We may have a rule to generate a potentially infinite sequence of rationals that will approximate an irrational 'number' such as $\sqrt{ } 2$ :

that for every number one should be able to find a square root, if necessary one that is itself no number, but only the rule to approximate it as closely as one wishes, ... (AA XI:210 ${ }^{7}$

But for Kant $\sqrt{ } 2$ and a sequence of rational approximations to it are two different things. This becomes clear when in his reply to Rehberg he writes of such a sequence as

a sequence of fractions that, because it can never be completed, although it can be brought as near to completion as one wishes, expresses the root (but only in an irrational way) (AA XI:209) ${ }^{8}$

Indeed, this incompletability served to characterize 'irrational' in one of Kant's Reflexionen of the same period:

Concepts of irrational ratios are those, that cannot be exhausted by any approximation. (AA XVIII:716, I790-1795?) 9

If Kant had thought that the square root could be identified with the potentially infinite sequence, he could not have said that the latter is an incomplete

welche die Qvantität (ihr Verhaltnis zur Einheit) deutlich und vollständig im Begriffe vorstellt. ... Daß aber der Verstand, der sich willkürlich den Begrif von $\sqrt{ } 2 \sqrt{ } 2$ macht, nicht auch den vollständigen Zahlbegrif, nämlich durch das rationale Verhaltnis derselben zur Einheit hervorbringen könne, ...'

7. 'daß sich zu jeder Zahl eine Qvadratwurzel finden lassen müsse, allenfalls eine solche, die selbst keine Zahl, sondern nur die Regel der Annäherung derselben, wie weit man es verlangt, ...'

8. 'eine ... Reihe von Brüchen ..., die, weil sie nie vollendet seyn kan, obgleich sich der Vollendung so nahe bringen läßt als man will, die Wurzel (aber nur auf irrationale Art) ausdrückt'.

9. 'Begriffe irrationaler Verhaltnisse sind solche, die durch keine Annäherung erschopft werden können.’ 
expression of the former. ${ }^{\text {Io }}$ Thus, although Kant at times speaks of 'irrational numbers' ${ }^{\text {II }}$ he also made it clear that this is a façon de parler, and that we actually only have rules for generating approximations.

In a foundational setting, to introduce real numbers as infinite sequences, one has to do two things:

I. Give a foundational account of infinite sequences as objects;

2. Explain in what sense such sequences can be considered to be numbers.

So when Kant rejects the identification, that can be on account of his concept of number, or on account of his foundational ideas about infinite sequences. Indeed, in his writings and correspondence, one finds objections of both kinds.

Kant's conception, mentioned above, that a number is composed out of given units, and that accordingly only whole numbers and rationals are numbers in the proper sense, goes back to the Greek. ${ }^{\mathrm{I2}}$ Note that Kant never adopted the more general concept of number as proportion, as, for example, Newton had; ${ }^{13}$ for the

Io. Note that, in the same sense, an infinite decimal expansion such as $0.333 \ldots$ would also be 'an irrational way' to express a magnitude, but in that case there is also the rational way of expressing it as a complete object, i.e., the fraction $1 / 3$. Hegel called the expression by infinite and hence incompletable means of something that can also be expressed finitely and hence completely a case of 'bad infinity' ('schlechte Unendlichkeit') (his example being the infinite decimal expansion $0.285714 \ldots$ and the fraction 2/7) (Hegel 1979, pp. 287-289). I thank Pirmin Stekeler-Weithofer for bringing this to my attention.

I I. A480/B508, AA XI:209, AA XIV:57, AA XVII:718.

I 2. For example, both Euclid (Elements, Book VII, def. 2) and Diophantus (Arithmetic, Book I, Introduction) define numbers as multitudes of units; while Euclid did not accept rational numbers, Diophantus did, in the sense that, as Klein explains it, 'by a fraction Diophantus meant nothing but a number of fractional parts' (Klein 1968, p. 137).

I 3. 'By number we understand not a multitude of units, but rather the abstract ratio of any one quantity to another of the same kind taken as unit. Numbers are of three sorts; integers, fractions, and surds: an integer is what the unit measures, the fraction what a submultiple part of the unit measures, and a surd is that with which the unit is incommensurable.' ('Per numerum non tam multitudinem unitatum quam abstractam quantitatis cujusvis ad aliam ejusdem generis quantitatem quae pro unitate habetur rationem intelligimus. Estque triplex; integer, fractus \& surdus: Integer quem unitas metitur, fractus quem unitatis pars submultiplex metitur, \& surdus cui unitas est incommensurabilis.') Newton, Arithmetica universalis, 
question addressed in the present paper, it would have made little difference if he had. ${ }^{14}$

Today, on the other hand, one would defend the claim that certain infinite sequences can be said to be numbers by referring to the algebraic concept of a field extension of the rationals. That is the result of a development starting with Abel and Galois and in which Hankel's Theorie der complexen Zablensysteme of I867 was of particular importance. ${ }^{15}$ Note that this algebraic concept is abstract enough not to depend on the particular way real numbers are implemented. Indeed, while Hankel thus extended the traditional concept of number, he still held that the existence of irrational numbers is shown only geometrically (Hankel I867, p. 59); ${ }^{16}$ his work preceeded the arithmetization of real numbers as infinite sequences of rationals by Cantor in 1872 (Cantor 1872 ). ${ }^{17}$ Cantor comfortably counted these sequences among the 'numerical quantities' ('Zahlengrösse'), ${ }^{18}$ and emphasized that on this conception, the real number is not an object that is distinct from the sequence, as limits in the original sense were.

Interestingly, Charles Méray, who three years before Cantor published the same mathematical ideas (Méray I869), and thus holds priority, ${ }^{19}$ had still pre-

sive de compositione et resolutione arithmetica liber (Cambridge, 1707) as quoted and translated in Petri and Schappacher 2007, p. 344.

I 4. Eudoxus' theory of proportions was, however, of great importance to Kant's views on the relations between arithmetic, geometry, and algebra. For an extensive treatment of that topic, see Sutherland 2006

I 5. I thank Carl Posy for drawing my attention to this.

I6. Tennant 20I0, "Why arithmetize the reals? Why not geometrize them?" (unpublished typescript) addresses the following question: "Who was the first major foundationalist thinker explicitly to reject (on the basis of reasons or argument, however inconclusive) recourse to geometric concepts or intuitions or principles or understanding, in the attempt to provide a satisfactory foundation for real analysis?', and argues that it was Bolzano. I am grateful to Tennant for sharing his typescript with me.

I7. Cantor's idea was first published, with credit, by Heine (1872, p. 173).

I 8. Kant also used that term (e.g., AA XI:208), but, as we will see, for him it did not refer to infinite sequences.

I9. As far as I know, Méray (I835-19II) and Cantor (I845-1918) have never been in contact; in particular, both as subject and as object Méray is completely absent from Cantor's known, rich correspondence with the French (Décaillot 2008). Méray states his priority claim on 
ferred to reserve the term 'nombres' for whole numbers and rationals (Méray I869, p. 284), ${ }^{20}$ and considered incommensurable numbers to be 'fictions' (Méray I872, p. 4). The infinite sequences he called 'variables progressives convergentes' instead. Thus, Méray in effect held a middle position between Kant's and Cantor's. The difference between Méray and Cantor is of course by no means merely terminological. ${ }^{2 \mathrm{I}}$

But even if Kant would have had occasion to consider extending the number concept the way Hankel would later suggest, ${ }^{22}$ he would, as we saw, still have seen reason to object to the identification of $\sqrt{ } 2$ and an appropriate potentially infinite sequence, because of the essential incompleteness of the latter. Now, compare this with Brouwer's position. Like Kant, Brouwer based his foundations of mathematics on an a priori intuition of time. ${ }^{23}$ Yet, Brouwer accepts the modern concept of number and moreover does identify real numbers and certain potentially infinite sequences: ${ }^{24}$

We call such an indefinitely proceedable sequence of nested ... intervals a point $P$ or a real number $P$. We must stress that for us the sequence ... itself is the point P.... For us, a point and hence also the points of a set,

p. XXIII of the 'préface' to Méray I 894 .

20. I do not know yet whether a reaction of Méray on Hankel's work is known.

$2 \mathrm{r}$. For a detailed history of the arithmetization of real numbers, see Boniface 2002 and Petri and Schappacher 2007.

22. One is reminded of the footnote (there, concerning the term 'analytic') in section 5 of the Prolegomena, which begins: 'It is impossible to prevent that, as knowledge advances further and further, certain expressions that have already become classical, dating from the infancy of science, should subsequently be found insufficient and badly fitting' ('Es ist unmöglich zu verhüten, daß, wenn die Erkenntniß nach und nach weiter fortrückt, nicht gewisse schon classisch gewordne Ausdrücke, die noch von dem Kindheitsalter der Wissenschaft her sind, in der Folge sollten unzureichend und übel anpassend gefunden werden') (AA IV:276n.)

23. Indeed, in his inaugural lecture 'Intuitionisme en formalisme' of 1912, Brouwer presented his position as fundamentally Kantian (Brouwer 1913, p. 85). That general qualification is absent from his later work; in the light of the considerations in the present paper, that seems, conceptually if not historically as well, to be no coincidence.

24. That Brouwer here describes a sequence of nested intervals, and not of rationals, is not essential to the question at hand. 
are always unfinished. (Brouwer 1992, p. 69, original emphasis)25

In what follows, I will leave aside the fact that Brouwer here also includes sequences that are constructed not according to a rule but by free choices. Even Brouwer's lawlike sequences, such as one for $\sqrt{ } 2$, would not themselves be real numbers for Kant. On the other hand, for Brouwer there is nothing irrational about the expression of a magnitude by an incompletable sequence.

Even before we ask whether or not a potentially infinite sequence is a rational way to express any kind of number, we can ask the ontological question whether the concept of such a sequence has constructible instances at all. There are three theses of Kant's that, taken together, at first sight seem to lead to a positive answer, along lines very similar to Brouwer:

I. We have an a priori intuition of time;

2. Time is given to us as infinite;

3. 'Time is in itself a sequence (and the formal condition of all sequences)' $\left(\mathrm{A} 4 \mathrm{II} / \mathrm{B}_{438}\right)^{26}$

Couldn't a potentially infinite sequence then be accepted as an object by labelling moments in the sequence of time with its elements? We will see, however, that Kant's understanding of these three theses is such that the answer to this question is negative.

Lisa Shabel has observed that Kant 'doesn't claim that the rule for the approximation of an irrational magnitude constitutes a "construction" of any kind' (Shabel 1998, p. 597n. I2); I took that to mean, among other things, that Kant does not claim that to generate a potentially infinite sequence of rationals according to an appropriate rule is to effect the construction of the mathematical

25. 'Ein derartige unbegrenzte Folge ineinander geschachtelter ... Intervalle nennen wir einen Punkt P order eine reelle Zahl P. Wir betonen, dass bei uns die Folge ... selbst der Punkt P ist ... Bei uns sind ein Punkt und daher auch die Punkte einer Menge immer etwas Werdendes.' 26. 'Die Zeit ist an sich selbst eine Reihe (und die formale Bedingung aller Reihen).' In KempSmith's translation, I have replaced 'series' by 'sequence'. 
concept of an irrational magnitude. ${ }^{27}$ Here I will defend the stronger thesis that for Kant, it would have been impossible to make that particular claim, as in his system we have no means to construct the concept of a potentially infinite sequence. A fortiori, Kant could not have arithmetized irrational quantities by infinite sequences.

Our considerations must begin with a review of what, for Kant, determines whether a mathematical concept can be constructed or not.

2 Mathematics within subjective limits

Kant takes the existence of mathematical knowledge as a given (B2O). He considers philosophy and mathematics two different enterprises that cannot and should not change one another. ${ }^{28}$ But they are closely related: mathematics can serve as an instrument in philosophy, and one of the tasks of philosophy is to give an answer to the transcendental question how mathematical knowledge (such as we indeed have it) is possible. ${ }^{29}$ In his lectures on logic, Kant emphasizes that the content of mathematics as a science is not influenced by the answer to the transcendental question. In the explanation what makes mathematical knowledge possible we cannot find motivations for revisions of mathematics. ${ }^{30}$

27. In an email, Lisa Shabel has confirmed to me that this indeed is included in her observation; I thank her for this clarification.

28. Various places in Kritik der reinen Vernunft, the Prolegomena; also AA XXIII:2OI.

29. 'For the possibility of mathematics must itself be demonstrated in transcendental philosophy." ('Denn sogar die Möglichkeit der Mathematik muß in der Transscendentalphilosophie gezeigt werden.') (A733/B76I); also Ar49/Bi88-I89.

30. 'Welche Bewandtniß es nun aber auch immer hiermit haben möge, so viel ist ausgemacht: in jedem Fall bleibt die Logik im Innern ihres Bezirkes, was das Wesentliche betrifft, unverändert; und die transscendentale Frage: ob die logischen Sätze noch einer Ableitung aus einem höhern, absoluten Princip fähig und bedürftig sind, kann auf sie selbst und die Gültigkeit und Evidenz ihrer Gesetze so wenig Einfluß haben, als auf die reine Mathematik in Ansehung ihres wissenschaftlichen Gehalts die transscendentale Aufgabe hat: Wie sind synthetische Urtheile a priori in der Mathematik möglich? So wie der Mathematiker als Mathematiker, so kann auch der Logiker als Logiker innerhalb des Bezirks seiner Wissenschaft beim Erklären und Beweisen seinen Gang ruhig und sicher fortgehen, ohne sich um die außer seiner Sphäre liegende transscendentale Frage des Transscendental-Philosophen und Wissenschaftslehrers 
The starting point for Kant's transcendental clarification of mathematics is his dictum 'Thoughts without content are empty, intuitions without concepts are blind' (A5I/B75). Mathematical knowledge can only be had if a concept and an intuition of an object are brought together. An intuition is necessary to show that a concept is related to an object, in other words, that a concept has objective reality (Ais5/Bi94). ${ }^{31}$ Even instances of analytic judgements count as mathematical knowledge only to the extent that they have been combined with appropriate intuitions:

Some few fundamental propositions, presupposed by the geometrician, are, indeed, really analytic, and rest on the principle of contradiction; ... And even these propositions, though they are valid according to pure concepts, are only admitted in mathematics because they can be exhibited in intuition. $(\mathrm{Br} 6-\mathrm{I} 7)^{32}$

According to Kant, the only kind of intuition humans have is sensuous in-

bekümmern zu dürfen: Wie reine Mathematik oder reine Logik als Wissenschaft möglich sei?' (AA IX:008)

3I. For phenomenologists, it is of interest that this is how Kant defines the notion of 'evidence':

When objective certainty is intuitive, it is called 'evidence' ('Wenn die obiective Gewisheit anschauend ist, so heisst sie evidentz.') (AA XVI:375 (1769? 1770?))

Mathematical certainty is also called evidence, as intuitive knowledge is clearer than discursive knowledge. ('Die mathematische Gewißheit heißt auch Evidenz, weil ein intuitives Erkenntniß klärer ist als ein discursives.') (AA IX:70)

Concepts a priori (in discursive knowledge) can never be a source of intuitive certainty, i.e., evidence, however much the judgement may otherwise be apodictically certain. ('Aus Begriffen a priori (im diskursiven Erkenntnisse) kann aber niemals anschauende Gewißheit, d. i. Evidenz entspringen, so sehr auch sonst das Urteil apodiktisch gewiß sein mag.') (A734/B762)

But it is not a term that Kant actually uses often.

32. 'Einige wenige Grundsätze, welche die Geometer voraussetzen, sind zwar wirklich analytisch und beruhen auf dem Satze des Widerspruchs; ... Und doch auch diese selbst, ob sie gleich nach bloßen Begriffe gelten, werden in der Mathematik nur darum zugelassen, weil sie in der Anschauung können dargestellet werden.' 
tuition (A5I/B75). This means that we can only have intuitions of objects that are given to us either in sense perception or in the imagination. Kant denies that humans can have intuition of (what we would call) abstract objects; we do not have intellectual intuition. On the other hand, he acknowledges that we do have purely mathematical knowledge. Kant is able to combine those two views by pointing out that a mathematical concept can be combined with a sensuous intuition, namely if the concept is exemplified or instantiated in it. ${ }^{33}$ In particular, then, on Kant's conception mathematics is not about sui generis mathematical objects, but about possible empirical instantiations of mathematical concepts. ${ }^{34}$ For example, the concept of the number five is instantiated in an image of five dots. Moreover, Kant says, when we think of a number (be it small or large) we are not so much thinking of such an image, as of a rule for producing images showing that number of objects (AI40/Bi79). The rule prescribes a series of acts in which an appropriate image will be brought about. Now, the number five will be equally well instantiated in an image of five dots, strokes, or yet another kind of object. By not stipulating that we use any of these in particular, but merely requiring that we be able to consider the things we are adding as in some sense homogeneous, the rule assumes a generality that accounts for the possibility of obtaining general knowledge through the acts of producing what is, after all, a particular image (see also what Kant says on triangles at A713-714/B74I-742). It is here that the inner sense of time comes in. Kant holds that all that we need

33. 'mathematica per constructionem conceptus secundum intuitionem sensitivam' (AA XVII:425 (1769? I773-1775?)); and various other places.

34. 'mathematics ... the object of that science is to be found nowhere except in possible experience' ('die Mathematik, [die] ihren Gegenstand nirgend anders, als in der möglichen Erfahrung hat') (A314/B37In.); 'Consequently, the pure concepts of understanding, even when they are applied to a priori intuitions, as in mathematics, yield knowledge only in so far as these intuitions - and therefore indirectly by their means the pure concepts also - can be applied to empirical intuitions' ('Folglich verschaffen die reinen Verstandesbegriffe, selbst wenn sie auf Anschauungen a priori (wie in der Mathematik) angewandt werden, nur so fern Erkenntniß, als diese, mithin auch die Verstandesbegriffe vermittelst ihrer auf empirische Anschauungen angewandt werden können') (BI47); '[the] mathematician ... who likewise deals only with possible objects of the outer senses' ('[der] Mathematiker ... der es auch blos mit möglichen Gegenständen äußerer Sinne zu thun hat') (AA XX:418) (1790). 
to be able successively to add units into one image is the inner sense of time (AI42-I43/BI82). ${ }^{35} \mathrm{~A}$ rule for producing images that instantiate a number concept need therefore not appeal to more than that inner sense. Because of this sufficiency, Kant can say that the foundation of arithmetic (tacitly, as a variety of human knowledge - see below) is the a priori intuition of time. In the series of acts prescribed by a rule, Kant says in his particular idiom, we 'construct the concept' (A713/B74I). Such a construction may be actually carried out (resulting in, e.g., an actual image of five dots) or, alternatively, be conceived of as an in some appropriate sense ideal possibility (an ideally possible image of one thousand clearly distinguishable and surveyable dots) (Ar40/Br79). What matters to Kant is not actual construction but ideal constructibility (see also Kant's reply to Eberhard in this matter: AA VIII:2IO-2I2, and the footnote on I9I-192). This invites of course a discussion what 'in principle' amounts to; for Kant, the idealization involved is constrained by what he takes to be the essential properties of the human mind. ${ }^{36}$

This view on numbers allowed Kant to accept as humanly constructible mathematical concepts not only the natural numbers but the rational numbers, too, by taking, to arrive at a particular rational number, whatever part of 1 is appropriate for unit. ${ }^{37}$ The concept of such a fractional unit is given intuitive content geometrically, by assigning length 1 to a given line segment and then constructing geometrically the required part of that segment (for example by the method of Euclid book VI, proposition 9).

But for Kant, to irrational numbers correspond no humanly constructible concepts. As mentioned, Kant held on to the Greek conception of number, which he could readily ground by his particular transcendental account of our

35. Hence, as Kant emphasizes in reflection 6314 (AA XVIII:616 (1790-179I)), for the representation of a number both time and space are necessary, as an image has a spatial character. See also 4629 (AA XVII:6I4) from between I77I and 1775 .

36. In the Kritik der Urteilskraft (AA V:254), Kant distinguishes between 'comprehensive' and 'progressive apprehension' ('comprehensive' and 'progressive Auffassung'), but to my mind in both cases what is aimed for is one (ideal) image; here I disagree with von Wolff-Metternich I995, pp. 57-6o.

37. Kant does this at, e.g., AA XIV:057 (draft to Rehberg) and AA XI:208 (letter to Rehberg). 
mathematical knowledge:

The concept of magnitude in general can never be explained except by saying that it is that determination of a thing whereby we are enabled to think how many times a unit is posited in it. But this how-many-times is based on successive repetition, and therefore on time and the synthesis of the homogeneous in time. $\left(\mathrm{A}_{242} / \mathrm{B}_{3} \mathrm{OO}\right)^{38}$

In the following elaboration of Kant's transcendental account, I will refer to a number of passages in his Reflexionen. Although the Reflexionen in general can certainly not be granted the same status as Kant's published work, the specific passages used below, which are all from 1769 or later, present a coherent view, which in turn is coherent with that presented in the first Kritik.

For Kant, to obtain an image out of a manifold of elements requires a synthesis of the imagination, which necessarily occurs in time. But, as a particularity of the human mind, in a finite time span, we can generate a manifold of only finitely many elements:

Progession. The infinity of the sequence as such is possible, but not the infinity of the aggregate. The former is an infinite possibility (of additions), the latter an infinite (actual) comprehension. (AA XVII:4I4, around I769I77I ${ }^{39}$

and, more generally,

What is only given by composition, is for that reason always finite, even

38. 'Den Begriff der Größe überhaupt kann niemand erklären, als etwa so: daß sie die Bestimmung eines Dinges sei, dadurch, wie vielmal Eines in ihm gesetzt ist, gedacht werden kann. Allein dieses Wievielmal gründet sich auf die sukzessive Wiederholung, mithin auf die Zeit und die Synthesis (des Gleichartigen) in derselben.'

39. 'Progression. Die Unendlichkeit der Reihe als solche ist möglich, aber nicht die Unendlichkeit des Aggregats. Jenes ist eine unendliche Möglichkeit (der Hinzuthuungen), dieses eine unendliche (wirkliche) Zusammennehmung.' 
though composition can go on infinitely. (AA XVIII:378 no. 5897 around $1780-1789$ ? $)^{40}$

As a consequence, Kant cannot accept any actually infinite totalities as objects of human mathematical knowledge. In particular, it would not be open to Kant to accept irrational numbers (and, more generally, real numbers) as actually infinite sums of rational numbers. But he also says that the ground of the impossibility of infinite composition lies not in the mathematical concept of infinity, but in the limits to the capacities of the human mind. Kant does not exclude that minds of a different type can grasp an infinite aggregate as a whole:

When a magnitude is given as a thing in itself, the whole precedes its composition, and in that case I cannot conclude from the fact that this putting together can never be finished and hence its quantitas can never be completely known, that such a thing, to the extent that it is an infinite quantum, is impossible. It is only impossible for us to know it completely according to our way of measuring magnitudes, because it is not measurable. From that it does not follow that a different understanding could not know the quantum as such completely without measuring. Similar for division. (AA XVIII:242-243, no. 559I (1778-1789)) $)^{41}$

(Exactly the same point was already made in the Inaugural Dissertation of 1770 (AA II:388 note $* *)$.)

Indeed, Kant says explicitly that our impossibility to grasp an infinite magnitude as a whole, an impossibility which follows from the dependence of our

40. 'Was nur durch die composition gegeben wird, ist darum immer endlich, obgleich die composition ins Unendliche geht.'

4I. 'Wenn eine Größe als ein Ding an sich selbst gegeben ist, so geht das Ganze vor der composition voraus, und da kann ich darum, daß diese zusammensetzung niemals vollendet werden und also die quantitas derselben niemals ganz erkannt werden kann, nicht schließen, daß ein solches qua unendliche quantum unmöglich sey. Es ist uns nur unmoglich, nach unserer Art großen zu messen es gantz zu erkennen, weil es unermeßlich ist. Daraus folgt nicht, daß nicht ein anderer Verstand ohne Messen das quantum als ein solches Ganz erkennen könne. Ebenso mit der Teilung.' Also e.g., AA XVIII:379 no. 5903. 
grasp of magnitudes on time, is not objective, but subjective:

In the infinite, the difficulty is to reconcile the totality with the impossibility of a complete synthesis. Therefore the difficulty is subjective. On the other hand, the potential infinite (infinity of potential coordination) is very well understandable, but without totality. (AA XVII:452 no. 4195 . $1769-1770$ ? $)^{42}$

and

How the conflict with subjective conditions or their presupposition mirrors the truth of the objective conditions and forces itself upon [unterschiebe] the latter. For example, a mathematical infinite is possible, as it does not conflict with the rules of the intellect [der Einsicht]; it is impossible, as it conflicts with the conditions of comprehension. (AA XVIII:I35 $1776-1778$ ? $)^{43}$

Kant's answer to the question what these subjective limits are for us is 'that which can be represented a priori in intuition, that is, space and time and change in time'. (AA XVII:70I (around I775-1777) ${ }^{44}$ I take it, then, that Kant's remark in the quotation above from $\mathrm{A}_{2} 42 / \mathrm{B}_{3} 00$ that the explanation of the notion of magnitude must depend on the notion of successive repetition and hence on time is limited to the specific context of human mathematical cognition, and that the same also holds for his statement at Ar42-I43/Bi82 that 'Number is therefore simply the unity of the synthesis of the manifold of a homogeneous

42. 'Im Unendlichen ist die Schwierigkeit, die totalitaet mit der unmöglichkeit einer synthesis completae zu vereinbaren. folglich ist die Schwierigkeit subiectiv. Dagegen ist das potentialiter infinitum (infinitum coordinationis potentialis) sehr wohl begreiflich, aber ohne totalitaet.'

43. 'Wie der Wiederstreit der subiectiven Bedingungen oder ihre Voraussetzung die Wahrheit der obiectiven nachahme und unterschiebe. e. g. Ein Mathematisch unendliches ist möglich, weil es den regeln der Einsicht nicht wiederstreitet; es ist unmöglich, weil es den Bedingungen der comprehension wiederstreitet.'

44. 'Welches sind die Grenzen der mathematischen Erkenntnis? Das, was a priori in der Anschauung kann vorgestellt werden, also Raum und Zeit und Veranderung in der Zeit.' 
intuition in general, a unity due to my generating time itself in the apprehension of the intuition'. ${ }^{45}$ I will now turn to the question what Kant's conception of mathematics within the subjective limits proper to us means for his view on real numbers. ${ }^{46}$

\section{Kant's discussion with Rehberg}

Rehberg's primary concern when writing to Kant in I790 was not the ontological status of real numbers, but the issue whether the intuition of time is really a condition of the possibility of mathematics for us. For our present purpose, the main interest of Rehberg's letter lies in two specific questions that are raised in it:

45. 'Also ist die Zahl nichts anderes, als die Einheit der Synthesis des Mannigfaltigen einer gleichartigen Anschauung überhaupt, dadurch, daß ich die Zeit selbst in der Apprehension der Anschauung erzeuge.'

46. Maimon, in his Versuch über die Transscendentalphilosopbie, also emphasizes the dependency on subjective conditions. Describing the division of a line segment into parts, he writes:

In case the parts are infinite [in number], then this division is, for a finite being, impossible, not, however, in itself. (Maimon I790, p. 375) ('Sind also die Theile unendlich, so ist diese Theilung, in Beziehung auf ein endliches Wesen, unmöglich, nicht aber an sich.' )

And, on infinite numbers:

An absolute understanding, on the other hand, thinks the concept of an infinite number without invoking a temporal sequence, all at once. Therefore, that which for the understanding [i.e., the human understanding] is, in accordance with its limitations, a mere idea, is, with respect to its absolute existence, a true object. (Maimon I79o, p. 228) ('Bei einem absoluten Verstande hingegen, wird der Begrif einer unendlichen Zahl, ohne Zeitfolge, auf einmal, gedacht. Daher ist das was der Verstand [i.e., the human understanding] seiner Einschränkung nach, als bloße Idee betrachtet, seiner absoluten Existenz nach ein reelles Objekt.')

It seems, then, that Maimon explicitly leaves open the possibility that infinite minds could admit into arithmetic not only whole and rational numbers, but also real numbers, as actually infinite sums of fractions. The human mind, however, cannot do this. 
I. What are the conditions of the possibility of knowing that $\sqrt{ } 2$ is irrational? Rehberg disputes Kant's claim at AI49/BI88-189 in the Kritik der reinen Vernunft that 'mathematical principles ... are derived solely from intuition, not from the pure cocnept of understanding'. ${ }^{7}$ While Rehberg agrees for the case of geometry, he disagrees for the case of arithmetic and algebra, and claims that in those domains the a priori intuitions of time and space are not necessary to obtain knowledge, but only the concepts themselves (AA XI:205-206). In his later comments, Rehberg calls the corresponding kind of intuition 'pure intellectual intuition ' ('reine Anschauung des Verstandes’) (Rehberg I828, p. 57).

2. 'Why is our understanding, which produces numbers spontaneously, unable to think numbers corresponding to $\sqrt{ } 2$ ?' (AA XI:206) ${ }^{48}$ It is not clear what Rehberg exactly means by 'thinking a number', 49 but the very fact that Rehberg, who must have known the infinite series, raises this question, suggests that generating an infinite series is not an example..$^{\circ}$

47. '[D]ie mathematischen Grundsätze ... [sind] nur aus der Anschauung, aber nicht aus dem reinen Verstandesbegriffe gezogen'.

48. 'Warum kann er [i.e., , der Verstand], der Zahlen willkührlich hervorbringt keine $\sqrt{ } \sqrt{ } 2$ Zahlen denken?' From Rehberg's letter and his later elaboration of his view (Rehberg I828, p. 56), it is clear that by 'willkürlich' he does not mean 'subject to no condition at all'. While he claims, against Kant, that it is a spontaneity that is unconstrained by the forms of time and space, he also thinks it is subject to constraints of a different kind (see footnote 50 below), and takes the impossibility, as he sees it, to think $\sqrt{ } 2$ in numbers as a proof of that fact.

49. Longuenesse claims that Rehberg means by it 'thinking in multiples or fractions of the unit, that is, in rational numbers' (Longuenesse 1998, p. 262n.38). (Also Dietrich reads him that way (Dietrich 1916, p. II8).) I do not find evidence for this in Rehberg's letter or his later comments. In effect, on that reading Rehberg is asking why the understanding cannot think an irrational number as a rational one. I read Rehberg differently; see the next footnote. (Of course, when Rehberg writes, 'Es heißt zwar p. I82 der Critik, daß die Zahl eine successive Addition sey' (AA XI:205), this formulation is neutral as to whether he agrees.)

50. Rehberg's own suggestion for an answer is that the ground of this impossibility lies in the transcendental faculty of the imagination and its connection to the understanding (AA XI:206), which he thinks has a property that limits our capacity of generating numbers in such a way that thinking [a quantum] in numbers for us is limited to 'discretely generated magnitudes' ('discretive erzeugten Größen') (Rehberg I828, pp. 57,59); see also Parsons 1984, p. III. In 
In his reply to Rehberg, Kant argues that time is, after all, involved in our coming to know the irrationality of $\sqrt{ } 2$, as follows..$^{\text {SI }}$ From the mere concept of a given natural number it cannot be seen whether its square root is rational or irrational. To determine this, Kant appeals to the following theorem: if the square root of a natural number $n$ is not itself a natural number, then it is not a rational number either (AA XI:209)..$^{2}$ We can only find out whether $n$ is the square of a natural number by testing. The test proceeds by constructing the natural numbers from 1 onward until the square is equal to or greater than $n .53$ But constructing numbers involves the intuition of time. And, although Kant

his letter he qualifies the nature of this faculty as 'transcending all human capacities of investigation“ (alles menschliche Untersuchungsvermögen übersteigend') (AA XI:206), but nevertheless goes on to suggest the possibility of a 'transcendental system of algebra' ('transscendentales System der Algebra'), which would serve to determine a priori, on the basis of principles, which equations we can solve and how. In one of the drafts for his reply, Kant says he can answer Rehberg's question 'without having to look into the first grounds of the possibility of a science of numbers' ('ohne auf die ersten Gründe der Moglichkeit einer Zahlwissenschaft zurüksehen zu dürfen') (AA XIV:55-56), but it is interesting that, decades earlier, he himself in a note had remarked: 'Philosophical insight into geometrical and arithmetical problems would be excellent. It would open the way to an art of discovery. But it is very difficult.' ('Ein philosophisch Erkentniß der geometrischen und Arithmetischen Aufgaben würde vortreflich seyn. sie würde den Weg zur Erfindungskunst bahnen. aber sie ist sehr schweer.') (AA XVI:55 (1752-W. S. 1755/56))

5 I. Given Kant's remarks quoted at the end of Sect. 2, I disagree with Friedman's claim that for Kant, 'the fact of the irrationality of $\sqrt{ } 2$, which is presumably a fact of pure arithmetic, is itself based on successive enumeration and hence on time' (Friedman 1992, p. II6, original emphasis). What depends on time is rather the possibility for humans to come to know that fact. See also Kant's letter to Schultz of November 25, 1788 (AA X:556-557) and Parsons' comments on it (Parsons 1984, pp. II6-II7).

52. This is known as Theaetetus' Theorem, although Plato's dialogue to which it owes its name gives no proof; for the ancient history of the theorem and its proofs, see Mazur 2007. Kant (who does not call the theorem by that name) may well have seen it, with a proof, in Sect. 137 of Johann Segner's Anfangsgründe der Aritbmetik (Segner 1764) to which he refers, in a different context, at Bis. The method to extract the square root of larger numbers that Kant refers to at AA XI:209 corresponds to the method given by Segner in Sect. 136. (The same material is also present in Michael Stifel's Arithmetica Integra (Stifel 1544) of which Kant owned a copy (Warda 1922, p. 40).)

53. Note that the procedure to extract roots in effect starts with the same test. 
does not remark on this in the letter, more generally, for him any algebraic means of establishing the irrationality of $\sqrt{ } 2$ could be said to depend on the a priori intuition of time, as for him it is characteristic of an algebraic proof as such that it 'exhibits all the procedure through which magnitude is generated and altered in accordance with certain rules in intuition' (A717/B745). ${ }^{54}$ 'Step by step', as Friedman comments on that statement (Friedman 1992, p. I20n. 42).

It is in reply to Rehberg's second question, why the understanding cannot think $\sqrt{ } 2$ in numbers, that Kant rejects, as we have seen, the identification of that square root with a certain potentialy infinite sequence, because of the essential incompletability of the latter. In the following, I attempt to reconstruct the ground on which for Kant this incompletability is objectionable.

4 Infinite sequences as concepts and as objects

One difference between a potentially infinite sequence and an image is that the parts of an image all exist simultaneously, whereas the parts (elements) of a potentially infinite sequence do not. ${ }^{55}$ In an image, the elements of the sequence that are not yet there obviously cannot be shown. Moreover, the fact that there are further elements yet to come, which is part of the concept of potentially infinite sequence, cannot itself be intuitively represented in the image. ${ }^{66}$ This is because

54. 'so stellet sie alle Behandlung, die durch die Größe erzeugt und verändert wird, nach gewissen allgemeinen Regeln in der Anschauung dar'.

55. Compare AA XVII:397 no. 4046 (1769? 1771?): 'The omnitudo collectiva in One or totality rests on the positione simultanea. From the multitudine distributiva I can conclude to the unitatem collectivam, but not from the omnitudine, because the progression is infinite and not complete.' ('Die omnitudo collectiva in Einem oder totalitaet beruhet auf der positione simultanea. Aus der multitudine distributiva kan ich auf die unitatem collectivam schließen, aber nicht aus der omnitudine, weil die Progression unendlich ist und nicht complet.'); also AA XVII:700 (around 1775-1777): 'The infinite of continuation or of collection. The infinitely small of composition or decomposition. Where the former is the condition, the latter does not occur." ('Unendlich der Fortsetzung oder der Zusammennehmung. unendlich klein der composition oder decomposition. Wo das erstere die Bedingung ist, findet das letztere nicht statt.'

56. Note that ideal, adequate givenness of a potentially infinite sequence does not consist in its being given as an actually infinite sequence (for that would contradict the essence of the object 
for Kant, there is nothing to the sequence that can be given intuitively, and hence synthesized, but the elements constructed so far themselves. ${ }^{57}$ (When we write $0.333 \ldots$, we understand what the three dots stand for, but the concept they instantiate is not that of infinity but of the number 3.) The understanding gives form to our sensuous intuitions by combining them in certain ways, but these forms are not themselves given to us in their own kind of intuition. In Husserl there is categorial intuition, but not in Kant..$^{8}$ Rather, Kant characterizes the human understanding as one

whose whole power consists in thought, consists, that is, in the act whereby it brings the synthesis of a manifold, given to it from elsewhere in intuition, to the unity of apperception - a faculty, therefore, which by itself knows nothing whatsoever, but merely combines and arranges the material of knowledge, that is, the intuition, which must be given to it by the object. (BI45) 59

qua potentially infinite), but in the givenness of the whole finite initial segment generated so far, however large the number of its elements may be, together with the open horizon that indicates the ever present possibility to construct further elements of the sequence. The absence of such further elements from an intuition of the sequence at a given moment does not make it an inadequate intuition, because they do not yet even exist. In contrast, the reason why our intuition of a physical object at a given moment is necessarily inadequate is precisely that, as a matter of three-dimensional geometry, any concrete view of it hides parts that do at that moment exist.

57. The order relation is represented by the relation between left and right, but that already requires an act of the understanding: do we take the order in a sequence to be from left to right, or from right to left?

58. 'It is true that in Kant's thought the categorial (logical) functions play a great role; but he never arrives at the fundamental extension of the concepts of perception and intuition over the categorial realm' ('In Kants Denken spielen zwar die kategorialen (logischen) Functionen eine große Rolle; aber er gelangt nicht zu der fundamentalen Erweiterung der Begriffe Wahrnehmung und Anschauung über das kategoriale Gebiet.') (Husserl 1984, p. 732).

59. 'dessen ganzes Vermögen im Denken besteht, d. i. in der Handlung, die Synthesis des Mannigfaltigen, welches ihm anderweitig in der Anschauung gegeben worden, zur Einheit der Apperception zu bringen, der also für sich gar nichts erkennt, sondern nur den Stoff zum Erkenntniß, die Anschauung, die ihm durchs Object gegeben werden muß, verbindet und ordnet'. See also A5I/B75, Bi38-139, Ar47/Bi86, B302-303n., A289/B345, Prolegomena sections 
We can therefore represent a potentially infinite sequence as a concept, and indeed use the concept to construct ever longer finite sequences, but we can never wholly instantiate that concept itself in an intuition. Hence, for Kant the concept of such a sequence is not mathematically constructible.

Note that the impossibility of a potential infinite sequence as a constructible mathematical concept has its ground in the requirement of an image rather than in a property of our capacity of synthesis. For it is the requirement of an image that imposes a condition of completeness (i.e., , the simultaneous presence of all its parts). ${ }^{60}$ This is also why for Kant it is irrational to try to arrive at a representation of a quantum by generating a potentially infinite sequence. On the other hand, Kant acknowledges that in principle the acts of synthesis can always be continued:

22, 39 and 57 .

6o. According to Kant, in pure mathematics all questions have a definite answer (or else the senselessness of the question can be demonstrated), and the same holds for transcendental philosophy and pure ethics (A476/B504ff.); see for discussion Posy I984, pp. I27-I28. The general reason Kant gives for this is that in these purely rational sciences, 'the answer must issue from the same sources from which the question proceeds' ('die Antwort aus denselben Quellen entspringen muß, daraus die Frage entspringt') (A476/B504). It seems to me that, when the details of this answer are spelled out for the case of pure mathematics, the condition of completeness that is imposed by Kant's requirement of an image must enter into the explanation. For intuitionistic mathematics is equally wholly concerned with spontaneous constructions in a priori intuition - where Kant speaks of questions raised by pure reason as concerned with its 'inner constitution' (innere Einrichtung) (A695/B723), Brouwer calls mathematics 'inner architecture' (Brouwer 1949, p. I249). But in intuitionism, the most we can justify in general is the weaker claim that there are no unanswerable questions, as $\neg \neg(p \vee \neg p)$ is demonstrable while $p \vee \neg p$ is not. For example, consider a potentially infinite lawless sequence of natural numbers $\alpha$ (which, as follows from the considerations in the present paper, for Kant would not be a mathematically constructible concept). We cannot, in general, show that $\exists n(\alpha(n)=0) \vee \neg \exists n(\alpha(n)=0)$, due to the open-endedness of such a sequence. We can show $\exists n(\alpha(n)=0)$ as soon as we have indeed chosen 0 in the sequence, but we are never obliged to make that choice. On the other hand, we can at any time show $\neg \neg(\exists \mathrm{n}(\alpha(\mathrm{n})=0) \vee \neg \exists \mathrm{n}(\alpha(\mathrm{n})=0))$ (which also shows that the original question is not senseless). Intuitionism, however, accepts Kant's claim for questions that ask whether a given construction of finite character is possible in a given finite system; e.g., Brouwer I949, p. I245. 
The infinity of synthesis in a sequence [is], as in a progression, only potential. (AA XVIII:277) ${ }^{61}$

and, to repeat an earlier quotation,

What is only given by composition, is for that reason always finite, even though composition can go on infinitely.' ${ }^{32}$

Of course, we may create an image of a finite sequence to construct the concept of an initial segment of a potentially infinite sequence, but the potentially infinite sequence is not thereby itself given in intuition. The difference is both philosophically and mathematically important: the collection of all finite sequences is denumerable, the collection of all potentially infinite sequences is not.

We also can associate to the concept of the potentially infinite sequence a schema, as a method to construct in intuition ever longer initial segments. Indeed, in his letter to Rehberg, Kant says that $\sqrt{ } 2$ 'is actually no number, but only a determination of magnitude by means of a rule of enumeration', and he seems to hold this for real numbers more generally. ${ }^{63}$ But as Kant emphasizes, in a different text and for a different reason, a schema is not itself an image (Ar42/BI8I). So Kant is not only saying that $\sqrt{ } 2$ is no number (in his sense), but that it is no proper object. Note also that the rule is, in one sense, given in intuition when written down. But that is not the sense needed here: the written rule is a finite object, whereas what is under discussion here is the intuition of a potentially infinite sequence. ${ }^{64}$

6r. 'Die Unendlichkeit der Synthesis in einer Reihe [ist] wie im progressu blos potential.'

62. AA XVIII:378 no. 5897 around 1780-1789?: 'Was nur durch die composition gegeben wird, ist darum immer endlich, obgleich die composition ins Unendliche geht.'

63. 'eine Irrationalzahl ... ist ... wirklich keine Zahl, sondern nur eine Großenbestimmung durch eine Regel des Zählens' (AA XIV:57) Compare in one of the drafts: 'a square root ..., but always such a one that is itself no number, but only the rule of approximation to it, however far one demands' ('eine Qvadratwurzel ..., allenfalls eine solche, die selbst keine Zahl, sondern nur die Regel der Annäherung zu derselben, wie weit man es verlangt') (AA XI:2Io).

64. Compare on this point also Wittgenstein: "We know the infinity from the description." Well, then only this description exists and nothing else.' ( "Wir kennen die Unendlichkeit 
Kant's acknowledgement that composition can go on infinitely certainly involves a knowledge that time is in some sense infinite, as all composition takes place in, and hence presupposes, time. What, then, of the suggestion (above, p. 8) that Kant's theses of time as infinite, given, and sequential, could provide a basis for the construction of infinite sequences?

Kant says that time, in its original representation, is not a concept, but is given to us, and as unlimited at that:

5. The infinitude of time signifies nothing more than that every determinate magnitude of time is possible only through limitations of one single time that underlies it. The original representation, time, must therefore be given as unlimited. But when an object is so given that its parts, and every quantity of it, can be determinately represented only through limitation, the whole representation cannot be given through concepts, since they contain only partial representations; on the contrary, such concepts must themselves rest on immediate intuition. $\left(B_{4} 7-48\right)^{65}$

But Kant denies that we can represent time itself in a mode of intuition proper to it, and repeatedly says that time itself cannot be perceived, e.g.: ${ }^{66}$

For time is not viewed as that wherein experience immediately determines

aus der Beschreibung.” Nun, dann gibt es eben nur diese Beschreibung und nichts sonst.') (Wittgenstein 1964, p. 155).

65. '5) Die Unendlichkeit der Zeit bedeutet nichts weiter, als daß alle bestimmte Größe der Zeit nur durch Einschränkungen einer einigen zum Grunde liegenden Zeit möglich sei. Daher muß die ursprüngliche Vorstellung Zeit als uneingeschränkt gegeben sein. Wovon aber die Teile selbst, und jede Größe eines Gegenstandes, nur durch Einschränkung bestimmt vorgestellt werden können, da muß die ganze Vorstellung nicht durch Begriffe gegeben sein (denn die enthalten nur Teilvorstellungen), sondern es muß ihnen unmittelbare Anschauung zum Grunde liegen.'

66. Here also, Brouwer and Husserl disagree with Kant; e.g., Brouwer (1907, pp. I04-I05), claims that the one-dimensional temporal intuitive continuum is given as an object without requiring the givenness of any other object; for Husserl, see Husserl 1928, in particular pp. 436-437 and $47 \mathrm{I}-473$. 
position for every existence. Such determination is impossible, inasmuch as absolute ${ }^{67}$ time is not an object of perception with which appearances could be confronted. $\left(\mathrm{A}_{215} / \mathrm{B}_{2} 62\right)^{68}$

According to Kant, we can represent time as an object only indirectly, by analogy ( $\mathrm{A}_{33}$ /B50), 'under the image of a line, in so far as we draw it' ('unter dem Bilde einer Linie, so fern wir sie ziehen') (Bi56). ${ }^{69}$ As soon as we conceptualize time, that is, come to think of it as an object to which concepts apply, then it has to be represented by a construction in space. ${ }^{70}$ Indeed, for Kant the intuitiveness of our representation of time is concluded to from the possibility to represent it spatially, and we derive all properties of time not from a direct representation of it, but from the line $\left(\mathrm{A}_{33} / \mathrm{B}_{5} \mathrm{O}\right)$ (except that the reference to the act of drawing is essential for the representation of succession (Bi54-I55)).

A consequence for Kant's view is that the intrinsic possibilities and limitations of spatial representation also condition our representation of time as an object. In the Transcendental Aesthetic, Kant argues that space is given to us as infinite (B39-40). An elucidation is given in a later manuscript, 'Über Kästners Abhandlungen' of $1790 .{ }^{71}$ Kant there distinguishes between mathematical

67. [By 'absolute', I take Kant here to mean 'not in relation to any objects whose appearances are temporally determined', in analogy to his explanation of the term 'absolute space' in the note at $\mathrm{A} 429 / \mathrm{B} 457$.

68. 'die Zeit wird nicht als dasjenige angesehen, worin die Erfahrung unmittelbar jedem Dasein seine Stelle bestimmte, welches unmöglich ist, weil die absolute Zeit kein Gegenstand der Wahrnehmung ist'. Also A32-33/B49, A37/B54, B219, B225, B226, B233, B257.

69. Following Böhme (1974, p. 272), I take it that Kant is referring not to time as such but to time in this relation to space and movement when he writes that 'The pure image ... of all objects of the senses in general is time' ('Das reine Bild ... aller Gegenstände der Sinne aber überhaupt, die Zeit') (Ar42/BI8I-I82).

70. AA XIV:55 (I790): 'But without space, time itself would not be represented as a magnitude and this concept would have no object at all.' ('Aber ohne Raum würde Zeit selbst nicht als Größe vorgestellt werden und überhaupt diese Begriff keine Gegenstand haben.')

7 I. AA XX:410-423, in particular 4I7ff. Written for, and indeed used by, Johannes Schultz; see the latter's 'Rezension von Johann August Eberhard, Philosophisches Magazin' (Schultz I790), and Kant's letters to Schultz of Summer I790: AA XI:I83, AA XI:I84, AA XI:200, AA XI:200-2OI. 
infinity and metaphysical infinity. It is the latter that according to Kant is 'an actual (but only metaphysically real) infinity'. ${ }^{72}$ It is actual because it is present in all of our experiences, and Kant therefore says this infinity is given to us. It is also metaphysical, because by that qualification Kant means that it pertains to the subjective forms of our sensibility. (The more usual notion of metaphysics Kant refers to as 'dogmatic metaphysics'.) At the same time, Kant repeats the point he had made, in somewhat different words, in the Transcendental Aesthetic (B39) that actual, metaphysical space cannot be brought under a concept that we would be capable of constructing. In fact, metaphysical, actual infinity is the precondition for the potential infinity of our mathematical constructions. It is the former that guarantees the presence of indeterminate space in which mathematicians construct determinate parts. ${ }^{73}$

As any such constructed determinate part will be finite, we can represent in a determinate way only finite segments of time in spatial intuition. When we represent such a finite segment of time by a finite line, the part of time that is yet to come, the future, is represented in an indeterminate way by the part of metaphysical, given space into which we have not yet extended the line but can do so if we wish. ${ }^{74}$ But as according to Kant metaphysical space as such is unconceptualizable, the finite line we have drawn and metaphysical, given space do not together make up an image in which the concept of a potentially infinite segment of time is constructed. Metaphysical space is not an image or part thereof, but a condition of possibility for images (see also footnote 69). This

72. That concise phrase occurs in a longer passage that Kant deleted; but the content of the passage agrees with the main text (in particular pp. 420-42I). The sentence containing this phrase runs: 'Denn daß man eine Linie ins Unendliche fortziehen oder Ebenen so weit man will aus einander rücken kan diese potentiale Unendlichkeit welche der Mathematiker allein seinen Raumesbestimmungen zum Grunde zu legen nöthig hat setzt jene actuelle (aber nur metaphysisch wirkliche) Unendlichkeit voraus und ist nur unter dieser Voraussetzung möglich.' (AA XX:4I8).

73. As the Transcendental Aesthetic is concerned with metaphysical infinity, not mathematical infinity, it gives necessary, but not sufficient conditions for mathematical cognition. These need to be completed by the Axioms of Intuition. See for a detailed discussion of this point Sutherland 2005.

74. See on this point Michel 2003, p. II2. 
means that we cannot represent time in intuition as a potentially infinite object. It follows that, although there is for Kant a specific sense in which time is given to us and is given to us as unlimited, this does not provide us with a basis for the construction of the concept of a potentially infinite sequence.

\section{Concluding remark}

The above arguments are general: for Kant the concept of no potentially infinite sequence whatsoever can be constructed by us, be it in a mathematical context or not. An incompletable process, even when fully specified, can never result in one, finished image..$^{75}$ In the case of the natural numbers, this means that Kant's position allows him to construct every one of them, one after the other, but not the potentially infinite sequence of them. It also means that Kant's position does not allow him to identify real numbers with potentially infinite sequences. (Likewise, any other explicit construction of a real number as an object out of infinitely many elements, such as a Dedekind cut, is impossible.) This changes when one recognizes what Husserl called 'categorial intuition', and accepts that the flow of time, together with its structuring moments of retentions and protentions, is given in an intuition proper to it; for this opens the possibility of applying categorial intuition to the flow of time, and then on that basis construct potentially infinite sequences as objects in intuition, as Brouwer did. That leads to a far richer mathematics. ${ }^{76}$

Acknowledgements. Earlier versions were presented at CUNY, New York, November 6, 2008; at REHSEIS, Paris, January 16, 2009; at the Oskar Becker Tagung, Bad Neuenahr/Ahrweiler, February 6, 2009; at IHPST, Paris, March 23, 2009;

75. In this sense, for Kant potentially infinite sequences would seem to be even more problematic than actually infinite ones; the latter might still be representable in an image by other minds than ours.

76. This is not to suggest that Husserl actually influenced Brouwer; rather, in my view, the ideas that Brouwer independently developed are best understood in the framework that Husserl provides. See van Atten 2007 for a phenomenological analysis of Brouwer's choice sequences. 
at Philosophy and Foundations of Mathematics: Epistemological and Ontological Aspects (a conference dedicated to Per Martin-Löf on the occasion of his retirement), Uppsala, May 7, 2009; at the meeting of the Société des études kantiennes en langue française, Lyon, September 8, 2009; at the joint philosophymathematics seminar (CEPERC/UFRAM) in Marseille, March Io, 2oIo; and at the logical-philosophical seminar at Charles University, Prague, March 28, 201 . I thank the audiences for their questions and comments, and also Carl Posy, Ofra Rechter, Lisa Shabel, Pirmin Stekeler-Weithofer, Neil Tennant, Robert Tragesser, and an anonymous referee.

\section{References}

Kant's works are referred to as follows:

A Kritik der reinen Vernunft. First edition. Hartknoch, Riga, I78I. Edition used: W. Weischedel (ed.), Suhrkamp, Frankfurt, 1974.

AA Gesammelte Schriften. Vols. I-XXIX. Hrsg. von der KöniglichPreussischen Akademie der Wissenschaften zu Berlin, 1902-.

B Kritik de reinen Vernunft. Second edition. Hartknoch, Riga, 1787. Edition used: W. Weischedel (ed.), Suhrkamp, Frankfurt, 1974.

English translations of AA are my own; those of A and B are taken from N. Kemp Smith's translation Immanuel Kant's Critique of Pure Reason, St. Martin's Press, New York, 1965.

van Atten, M. 2007. Brouwer Meets Husserl. On the Phenomenology of Choice Sequences. Dordrecht: Springer.

Beiser, F. 2008. "August Wilhelm Rehberg". In The Stanford Encyclopedia of Philosophy. Ed. by E. Zalta. http://plato.stanford.edu/archives/winzoo8/ entries/august-rehberg/. CSLI.

Böhme, G. 1974. Zeit und Zabl. Studien zur Zeittheorie bei Platon, Aristoteles, Leibniz und Kant. Frankfurt a.M.: Klostermann. 
Boniface, J. 2002. Les constructions des nombres réels dans le mouvement d'arithmétisation de l'analyse. Paris: Ellipses.

Brouwer, L.E.J. 1907. Over de grondslagen der wiskunde. PhD thesis. Universiteit van Amsterdam.

- 1913. "Intuitionism and formalism". Bulletin of the American Mathematical Society 20, 8I-96.

- 1949. "Consciousness, philosophy and mathematics". Proceedings of the Ioth International Congress of Philosophy, Amsterdam 1948 3, pp. I235-I249.

- 1992. Intuitionismus. Mannheim: Bibliographisches Institut, Wissenschaftsverlag.

Cantor, G. 1872. "Über die Ausdehnung eines Satzes aus der Theorie der trigonometrischen Reihen". Mathematische Annalen 5, I23-132.

Décaillot, A.-M. 2008. Cantor et la France. Correspondance du mathématicien allemand avec les Français à la fin du XIXe siècle. Paris: Éditions Kimé.

Dietrich, A.J. 1916. Kants Begriff des Ganzen in seiner Raum-Zeitlebre und das Verbältnis zu Leibniz. Halle a.S.: Niemeyer.

Friedman, M. 1992. Kant and the Exact Sciences. Cambridge, MA: Harvard University Press.

Hankel, H. 1867. Vorlesungen über die complexen Zablen und ibre Functionen. I. Teil. Theorie der complexen Zablensysteme. Leipzig: Voss.

Hegel, G.F.W. 1979. Wissenschaft der Logik. I. Teil, I. Band: Die Lehre vom Sein. Vol. s. Werke. Frankfurt a.M.: Suhrkamp.

Heine, E. 1872. "Die Elemente der Functionenlehre". Journal für die reine und angewandte Mathematik 74, 172-188.

Husserl, E. 1928. "Vorlesungen zur Phänomenologie des inneren Zeitbewußtseins". Jabrbuch für Philosopbie und phänomenologische Forschung IX, 367498.

- 1984. Logische Untersuchungen. Zweiter Band, 2. Teil. Vol. XIX/2. Husserliana. Den Haag: Martinus Nijhoff.

Klein, J. 1968. Greek mathematical Thought and the Origin of Algebra. Cambridge MA: MIT Press.

Longuenesse, B. 1998. Kant and the Capacity to Judge. Princeton: Princeton University Press. 
Maimon, S. 1790. Versuch über die Transscendentalphilosophie. Berlin: Voß und Sohn. Digital edition by Andreas Berger, Tübingen, October 2003 (Version A I.Iß). URL = http://tiss.zdv.uni-tuebingen.de/webroot/fp/fpsfroI_Wo304/ dokumente/Maimon-VTP-Normal.pdf. Page references are to the original. Note added in 2017: The link to be used now is http://web.archive.org/web/ 20070330030817/http://tiss.zdv.uni-tuebingen.de/webroot/fp/fpsfroI_ wo304/dokumente/Maimon-VTP-Normal.pdf.

Mazur, B. 2007. "How did Theatetus prove his theorem?” In The Envisoned Life: Essays in Honor of Eva Brann. Ed. by P. Kalkavage and E. Salem. Philadelphia: Paul Dry Books, 227-250.

Méray, C. 1869. "Remarques sur la nature des quantités définies par la condition de servir de limites à des variables données”. Revue des Sociétés Savantes 4, $280-289$.

- 1872. Nouveau précis d'analyse infinitésimale. Paris: Savy.

- I894. Leçons nouvelles sur l'analyse infinitésimale et ses applications géométriques. Première partie. Principes généraux. Paris: Gauthiers-Villars et fils.

Michel, K. 2003. Untersuchungen zur Zeitkonzeption in Kants Kritik der reinen Vernunft. Berlin: De Gruyter.

Parsons, C. 1984. "Arithmetic and the categories". Topoi 3(2), 109-122.

Petri, B. and N. Schappacher 2007. "On arithmetization". In The shaping of arithmetic: after C.F. Gauss's Disquisitiones Arithmeticae. Ed. by C. Goldstein, N. Schappacher, and J. Schwermer. Berlin: Springer, 343-374.

Posy, C. 1984. "Kant's mathematical realism". The Monist 67(I), II5-I34.

Rehberg, A. 1828. Saemtliche Schriften. Vol. I. Hannover: Hahn.

Schultz, J. I790. "Rezension von Johann August Eberhard, Philosophisches Magazin”. Jenaer Litteraturzeitung (28I-284).

Segner, J.A. von 1764. Anfangsgründe der Arithmetik. Translation and revision by J.W. Segner of his father's Elementa arithmeticae geometriae (2nd edition, 1756). Halle: Renger.

Shabel, L. 1998. "Kant on the symbolic construction of mathematical concepts". Studies in the History and Philosophy of Science 29(4), pp. 589-621.

Stevin, S. 1585. L'Aritbmétique. Leyde: Plantin.

Stifel, M. 1544. Arithmetica Integra. Nürnberg: Petreius. 
Sutherland, D. 2005. “The point of Kant's axioms of intuition”. Pacific Philosophical Quarterly 86, pp. 135-159.

- 2006. "Kant on arithmetic, algebra, and the theory of proportions". Journal of the History of Philosophy 44(4), 533-558.

Tennant, N. 2oio. "Why arithmetize the reals? Why not geometrize them?" Unpublished typescript.

Warda, A. 1922. Kants Bücher. Berlin: Breslauer.

Wittgenstein, L. 1964. Philosophische Bemerkungen. Oxford: Blackwell.

von Wolff-Metternich, B.-S. 1995. Die Überwindung des mathematischen Erkenntnisideals. Kants Grenzbestimmung von Mathematik und Philosophie. Berlin: De Gruyter. 